Ariane setback makes problems for European space plans

Paris

THF European space industry, which entered 1988 determined to make up for the 16-month setback following problems with its Ariane rocket launchers, is already running late. Despite the successful resumption of Ariane launches in September 1987, the next two flights, V21 and V22, will to be delayed. This will make it hard for Arianespace to fulfil its pledge to launch 8 or 9 rockets this year, even though two launch facilites are now available at Kourou in French Guiana.

The next Arianespace launch (V21) has already been postponed once, because of new doubts about Ariane's third-stage rocket motor. But the new delay - until 11 March - is due to a problem in the payload. The power unit of Telecom $1 \mathrm{C}$, one of the two satellites to be launched by V21, has been sent back to its manufacturer, Matra, for emergency revisions.

The satellite's sister, Telecom 1B, stopped transmitting last month when its power supply failed, only 2 years into its expected 7-year life, forcing the French PTT and the Defence Department, its principal users, to switch to the older Telecom 1A satellite. If the mid-March

\section{Space station accord}

\section{Munich}

AFTER years of negotiations, an agreement on the use of the space station Columbus seems very close to being reached by the United States and the European Space Agency (ESA).

It has been difficult to find an acceptable common viewpoint on military use of the space station, to which the European partners are largely opposed, and an equitable way to apportion rights to research results obtained on board the station.

The West German Research and Technology Ministry (BMFT) confirmed reports that significant progress had been made in the latest round of negotiations in Washington last week. A BMFT spokesman said that a memorandum of understanding is expected "in the foreseeable future". West German Research and Technology Minister Heinz Riesenhuber met last week in Washington with US Secretary of State George Shultz. Riesenhuber is currently head of the ESA Council of Ministers.

The spokesman would not comment on reports that the agreement hinged on US capitulation in the area of military research in space. After the details have been settled, it now seems likely that further formal negotiations will not be necessary. Steven Dickman launch of V21 is to go ahead, the new power supply will have to be delivered to Kourou this week.

Although delays to flight V21 are irritating, Arianespace and the European Space Agency have more reason to be concerned about flight V22. Now scheduled for May 1988 , this is to be the first launch of the improved Ariane 4 rocket. Extensive tests on the third-stage cryogenic motor show that the redesigned turbo-pump is registering higher temperatures than specified. It was a turbo-pump failure that stopped V18 in May 1986, only seconds after liftoff, bringing Europe's commercial space industry to an abrupt and costly standstill.

A successful launch of Telecom $1 \mathrm{C}$, even behind schedule, would end a recent run of bad luck with European communications satellites. Not only is Telecom 1B out of action, but West Germany's TVSAT 1, put into orbit by Arianespace's last launch, still has only one of its two solar panels operational (see Nature 331, 200; 1988). Plans to launch TV-SAT's French twin, TDF-1, have now been put back until autumn, and with it West Europe's entry into direct satellite television broadcasting.

Peter Coles

\section{New DNA guidelines}

\section{San Jose, Costa Rica}

THE first guidelines for recombinant DNA genetic engineering work in Latin America have been adopted by a group of Pan-American scientists, in an effort to encourage biotechnology work while providing adequate protection.

Last week's conference of the Interamerican Institute for Cooperation in Agriculture (IICA) was spurred by a decision of Pan-American agriculture ministers in Ottawa last year to encourage biotechnology as a means of revitalizing agriculture in the region. The adoption of the guidelines has also stemmed from fears of "dumping" of uncontrolled genetic engineering experimentation in joint ventures with scientists from more developed countries. Latin Americans are also concerned that agriculture development in the region may suffer if genetic engineering work is not tailored specifically.

The guidelines are based on similar rules already adopted in other countries They allow regulatory committees to be set up, define the type of experiments requiring approval, classify hazards and put controls on experiments with plants, medicines and foods.

The guidelines will be distributed throughout Latin America with a grant from the Interamerican Development Bank.

Kathy Johnston

\section{No irradiation yet}

THE British government's proposals to permit the irradiation of food have been put on ice following intense public opposition. The government accepts the advice of the Advisory Committee on Irradiated and Novel Foods (ACINF) that ionizing radiation can be used safely to improve shelf-life, but concedes that the technique could be used to "clean" unfit food (see Nature 328, 751; 1987). In April 1986, two weeks before the Chernobyl incident, the ACINF published a report advising that irradiation was safe. Last week, it published its response to comments received on the original report. It says that of the 6,000 letters received from members of the public and $\mathbf{1 5 0}$ from organizations, "almost all respondents expressed some form of concern about food irradiation".

The report says there is no evidence to support many of the concerns expressed: the formation of toxic radiolytic products, the possibility of free radicals being ingested, or the loss of nutritional value. The government says the process will nevertheless remain outlawed until suitable regulatory controls are devised, including a method to detect whether food has been irradiated.

S. H.

\section{Turks in the Aegean}

THE Turkish research ship Piri Reis, belonging to the Marine Sciences Institute of the "Ninth September" University of Izmir, is back in the Aegean, this time researching on pollution. Last year, while conducting a geological survey in the same area, the Piri Reis was kept under close surveillance by Greek naval vessels, whose tactics, on one occasion at least, alarmed the Turks considerably. This year, according to a Greek government spokesman, Ioannis Roumbatis, there should be no trouble, as there will be no infringement of Hellenic sovereignty so long as the Piri Reis stays in the international waters of the Aegean to study pollution.

V. R.

\section{Medical merger off}

CURRENCY fluctuations have been blamed for the collapse of a planned joint venture between Britain's General Electric Company (GEC) and Philips, of the Netherlands, to create the world's largest company producing medical diagnostic systems. Last April, the two companies announced the merger of Philips' medical systems division and GEC's Picker International subsidiary (see Nature 326, 817; 1987). The new company would have specialized in computed tomography and magnetic resonance systems, with an expected turnover of $\$ 2,000$ million. It is believed that disagreement over GEC's investment in the new company, to compensate for its smaller size, led to the deal's eventual failure. It seems likely that both companies will look for other partners. S.H. 